Acta vet. scand. $1969,10,127-136$.

From the Department of Special Pathology and Therapeutics, Royal Veterinary and Agricultural University, Copenhagen, Denmark.

\title{
THE USE OF A SELECTIVE MEDIUM \\ IN THE GROWTH-AGGLUTINATION TEST FOR CHRONIC ERYSIPELOTHRIX INSIDIOSA INFECTIONS IN SWINE*)
}

\author{
By \\ N. C. Nielsen
}

With the increasing frequency of osteoarthropathies, legweakness and arthritis in swine populations the need of a reliable, economic serologic test for the diagnosis of chronic E. insidiosa infection on a herd basis has become most actual in the differential diagnosis. The methods of choice have been the tube and plate agglutination tests and the growth-agglutination test or Wachstumsprobe (WP), whereas the precipitation test and the hemagglutination inhibition test are more suited for research work and serologic typing of strains.

The agglutination test was introduced by Schoening et al. in 1932. Since then the test has been used by several investigators (i. a. Schoening \& Creech 1933, 1935 a, b, Watts 1940, Collins \& Goldie 1940, Grey et al. 1941, Rice et al. 1952, Freeman et al. 1964, Sikes 1965), who have changed and improved the method for preparing the antigen and the technique for conducting the test. The main difficulties in adapting the test to a practical diagnostic method have been: The tendency of many erysipelas strains to agglutinate spontaneously, the short-term stability of a prepared stock antigen and the interpretation of low-grade reactions since many normal swine sera show a tendency to agglutinate E. insidiosa non-specifically in low dilutions. Fond.

*) Supported by a grant from Statens teknisk-videnskabelige 
Recently Sikes \& Tumlin (1967) have developed and described a technique for preparing antigen for the tube agglutination test which increases the term of stability and potency of the antigen from 1 week to 6 weeks. Also Schaaf \& Kramer-Zeeuw (1968) reported on the production of a stable antigen which may facilitate the diagnostic use of the tube agglutination tests for chronic E. insidiosa infections.

The use of growing erysipelas organisms as antigen in a serum agglutination test was briefly reported by Watts in 1940, and in the fifties Wellmann and co-workers developed and extensively used a growth-agglutination test (WP) together with the hemagglutination inhibition test and the slow tube agglutination in detecting humoral antibodies to E. insidiosa in experimental pigs. They found the WP very reliable in detecting immunity (Wellmann 1955, Wellmann \& Heuner 1957a, b, 1959, Wellmann \& Liebke 1960, Hubrig 1961).

In this laboratory we have been working with the WP concurrently with the tube agglutination test. In the diagnosis of chronic E. insidiosa infections Nielsen (1969) found the WP as specific as the tube agglutination test and easier as to interpretation and conduction. The main obstacle to a wide application of the test has been that serum for testing must be bacteriologically sterile. As it is most difficult to avoid slight contamination during bleeding procedure in a swine herd, during shipment and during routine serum preparation, the majority of samples has to be sterilized by filtration before testing. This is a rather laborious procedure especially when no precautions can be taken to minimize the lipid content which is often very high in serum from young pigs.

In 1965 Wood described a selective liquid medium with antibiotics which permitted multiplication of E. insidiosa and exerted considerable inhibition on fecal contaminants. This report describes the use of Wood's combination of antibiotics in the growth-agglutination test.

\section{MATERIALS AND METHODS}

The serums used in testing the method are divided in 4 groups:

Group A. Blood samples were collected aseptically from the anterior vena cava from 5 arthritic pigs shortly before slaughter- 
ing. During separation of the serum bacteriologic sterility was secured and the serum was stored at $-20^{\circ} \mathrm{C}$.

Group B. Blood was collected at slaughtering from the same 5 pigs as group A serums. The serum was separated and stored at $-20^{\circ} \mathrm{C}$ in a clean way, but sterility was not attempted. Before use a part of each sample $(4 \mathrm{ml})$ was sterilized by filtration $\left.^{*}\right)$. The other part was used untreated.

Group $C$. Blood samples were collected from 6 rabbits before and during immunization with killed $\mathrm{E}$. insidiosa antigen. The rabbits were bled by cutting a marginal ear vein; aseptic procedure was not employed during serum separation. After separation the samples were stored at $-20^{\circ} \mathrm{C}$.

Group $D$. One hundred and fifty-six blood samples were collected from the anterior vena cava from pigs with osteoarthropathies at an experimental farm (Sjælland II). The bleeding procedure was carried out in a professionally clean way, but bacteriologic sterility of the samples was not aimed at. After separation the serum samples passed 2 laboratories for chemical analyses. When not in use the samples were kept refrigerated at $+4^{\circ} \mathrm{C}$ and finally stored at $-20^{\circ} \mathrm{C}$ before screening for $\mathrm{E}$. insidiosa antibodies.

Medium. As medium was used horse meat infusion broth with $1 \%$ peptone ${ }^{\star \star}$ ) and $0.5 \% \mathrm{NaCl}$. The $\mathrm{pH}$ was adjusted to 7.8. The medium was boiled for 15 min., phosphate-buffered (10.8 $\mathrm{g} \mathrm{Na}_{2} \mathrm{HPO}_{4}$ and $0.8 \mathrm{~g} \mathrm{KH}_{2} \mathrm{PO}_{4}$ per l) and $\mathrm{pH}$ adjusted to 7.8 , paper-filtered and sterilized by autoclaving. The final $\mathrm{pH}$ was $7.7-7.8$.

The selective medium was prepared by adding antibiotics as recommended by Wood. The final concentrations used were: Neomycin-sulphate $50 \mu \mathrm{g} / \mathrm{ml}$, kanamycin ${ }^{\star \star \star}$ ) $400 \mu \mathrm{g} / \mathrm{ml}$ and vancomycin $\left.{ }^{\circ}\right) 25 \mu \mathrm{g} / \mathrm{ml}$. The selective medium was used within 4 days after adding the antibiotics ${ }^{\circ}{ }^{\circ}$ ).

*) Swinny adapter with Seitz filter discs no. 423 FD, Becton, Dickinson \& Co., Rutherford, N. J., USA.

**) Bacto-peptone, Difco Lab., Detroit, Mich., USA.

**) Kantrex $\circledast$, H. Lundbeck \& Co., A/S, Copenhagen, Licence from Bristol Lab. Inc., Syracuse, N. Y., USA.

-) Vancocin $\AA^{\circ}$, Eli Lilly \& Co., Indianapolis, Ind., USA.

${ }^{\circ}$ ) In a pilot test, however, the selective medium was kept refrigerated for 3 weeks without losing inhibitory efficiency when tested with 10 randomly selected contaminated serum samples. 
Antigens. As inoculums for the growth-agglutination test on groups A, B and D serums were used pure $18 \mathrm{hrs}$. broth cultures of the E. insidiosa strains 57/65 (homologous to one of the serums in groups A and B), and strain $\left.\mathrm{HC}-585^{\star}\right)$. The group C serums were only tested with strain HC-585.

Procedure. For groups A and B serums the medium without inhibitors and the selective medium were used. For groups $\mathrm{C}$ and D serums only the selective medium was used. When using the medium without inhibitors bacteriologic aseptical technique was employed. For each antigen, two-fold serial dilutions of the serum were made in tubes with $2 \mathrm{ml}$ broth - tube 1 dilution being $1: 2.5$ (40\% serum content) and tube 7 dilution being 1:160. The serum broth dilutions were incubated $24 \mathrm{hrs}$. at $37.5^{\circ} \mathrm{C}$. When no visible growth occurred, the tubes (except no. 5) were inoculated with 1 drop of the antigen. For each set up, tubes without serum were included. The test was read after $18 \mathrm{hrs}$. reincubation at $37.5^{\circ} \mathrm{C}$. If there was definite clearing of the medium, with clumping of the multiplied organisms, the reaction was regarded positive, and negative when slight aggitation showed organisms suspended in the medium - regardless of some sedimentation. Tube 5 served as further control of sterility and - when indicated - used for additional dilutions.

When performing the test with the selective medium the same procedure was followed except for the dilution technique. The medium was measured into the tubes with a semiautomatic laboratory pipette and the tubes remained uncapped until the serial serum dilutions were finished.

\section{RESULTS}

Test for the agglutination reaction in the selective medium.

The addition of inhibitory agents to the medium caused no visible growth depression on the antigens regardless of the percentage $(\leqq 40 \%)$ of specific hyperimmunserum content.

The use of the selective medium in testing hyperimmunserum (groups A and B) revealed no significant difference in the recorded antibody titer as compared to the ordinarily used medium (Table 1). The presence of some contaminants in the agglutinat-

*) Kindly supplied by Dr. R. D. Shuman, Nat. Anim. Dis. Lab., US Dept. Agric., Ames, Iowa, USA. 
T a b l e 1. Growth-agglutination test with selective and non-selective medium on sterile and contaminated serums.

\begin{tabular}{|c|c|c|c|c|c|c|}
\hline \multirow[b]{2}{*}{$\begin{array}{l}\text { Serum no. } \\
\text { Group }\end{array}$} & \multirow[b]{2}{*}{ Antigen strain } & \multicolumn{5}{|c|}{ Antibody titer. Selective medium } \\
\hline & & $329 / 63$ & $332 / 63$ & $440 / 63$ & $13 / 64$ & $57 / 65$ \\
\hline $\mathbf{A}$ & $\begin{array}{l}\text { HC-585 } \\
57 / 65\end{array}$ & $\begin{array}{l}1: 320 \\
1: 320\end{array}$ & $\begin{array}{l}1: 320 \\
1: 320\end{array}$ & $\begin{array}{l}1: 1280 \\
1: 1280\end{array}$ & $\begin{array}{l}1: 320 \\
1: 320\end{array}$ & $\begin{array}{l}1: 640 \\
1: 1280\end{array}$ \\
\hline $\begin{array}{l}\text { B (sterile } \\
\text { filtr.) }\end{array}$ & $\begin{array}{l}\text { HC-585 } \\
57 / 65\end{array}$ & $\begin{array}{l}1: 320 \\
1: 160\end{array}$ & $\begin{array}{l}1: 320 \\
1: 160\end{array}$ & $\begin{array}{l}1: 640 \\
1: 1280\end{array}$ & $\begin{array}{l}1: 160 \\
1: 320\end{array}$ & $\begin{array}{l}\text { 1: } 640 \\
1: 640\end{array}$ \\
\hline $\begin{array}{l}\text { B (un- } \\
\text { treated) }\end{array}$ & $\begin{array}{l}\mathrm{HC}-585 \\
57 / 65\end{array}$ & $\begin{array}{r}1: 320 \\
1: 320 \\
\text { Antibody }\end{array}$ & $\begin{array}{c}1: 320 \\
1: 320 \\
\text { ter. Non }\end{array}$ & $\begin{array}{l}1: 640 \\
1: 1280 \\
\text { selective }\end{array}$ & $\begin{array}{r}1: 320 \\
1: 320 \\
\text { edium }\end{array}$ & $\begin{array}{r}\text { 1: } 640 \\
\text { 1: } 640 \\
\text { control) }\end{array}$ \\
\hline A & $\begin{array}{l}\text { HC-585 } \\
57 / 65\end{array}$ & $\begin{array}{l}1: 320 \\
1: 320\end{array}$ & $\begin{array}{l}1: 320 \\
1: 320\end{array}$ & $\begin{array}{l}1: 640 \\
1: 1280\end{array}$ & $\begin{array}{l}1: 320 \\
1: 320\end{array}$ & $\begin{array}{l}1: 640 \\
1: 1280\end{array}$ \\
\hline $\begin{array}{l}\text { B (sterile } \\
\text { filtr.) }\end{array}$ & $\begin{array}{l}\mathrm{HC}-585 \\
57 / 65\end{array}$ & $\begin{array}{l}1: 320 \\
1: 160\end{array}$ & $\begin{array}{l}1: 160 \\
1: 160\end{array}$ & $\begin{array}{l}\text { 1: } 640 \\
1: 640\end{array}$ & $\begin{array}{l}1: 320 \\
1: 160\end{array}$ & $\begin{array}{l}\text { 1: } 320 \\
\text { 1: } 640\end{array}$ \\
\hline $\begin{array}{l}\text { B (un- } \\
\text { treated) }\end{array}$ & - & *) & $\left.{ }^{*}\right)$ & $\left.{ }^{*}\right)$ & $\left.{ }^{*}\right)$ & $\left.{ }^{*}\right)$ \\
\hline
\end{tabular}

*) indicates turbidity in all dilutions before inoculation with antigen.

ing system did not influence the result of the test, provided that the multiplication of these organisms was inhibited. Without inhibitory agents the serum broth dilution showed turbidity in all tubes after $24 \mathrm{hrs}$. incubation prohibiting the performance of the agglutination test (Table 1, group B untreated). A tendency of the sterile filtrated group B serums to give some weaker reaction ( $1-2$ tubes) was noticed in both media. There was no significant difference in the behaviour of the 2 antigens used.

Test for inhibitory efficiency.

Groups $B$ and $C$ serums. None of the selective broth dilutions of the untreated group B serums and the rabbit serums showed any turbidity after the $24 \mathrm{hrs}$. preincubation, and the control tube no. 5 remained clear in all series after $48 \mathrm{hrs}$. incubation. There was excellent growth of both antigens in the inoculated tubes after $24 \mathrm{hrs}$.

Group D serums. Multiplication of contaminants in the se- 
rum broth dilutions was not observed. However, of the 156 serum samples 11 showed obvious turbidity in tubes 1 and 2 (1:2.5 and $1: 5$ ) and slight turbidity in tubes 3 and 4 immediately after dilution. Microscopic examination from the tubes revealed numerous coccoid elements. The $24 \mathrm{hrs}$. preincubation did not result in any increase of the turbidity in the lower dilutions or occurrence of visible growth in the higher dilutions. From all tubes with turbidity $0.1 \mathrm{ml}$ was spread on $5 \%$ blood agar plates. No growth occurred after $72 \mathrm{hrs}$. incubation.

For the remaining serums in group $D$ there were no difficulties in reading the test in low dilutions.

\section{DISCUSSION}

The results obtained proved the antibiotic combination to be very suitable in the growth-agglutination test on positive and negative swine and rabbit serums. The $100 \%$ inhibitory effect observed in testing the 173 contaminated serums indicates that the number of serums, which have to be sterilized by filtration before screening a swine herd for E. insidiosa antibodies, can be reduced considerably - or even omitted. However, heavy growth of contaminants in the serum samples must be avoided, not only because the multiplied organisms prohibit the reading of the test in low dilutions without previous filtration or clearing by centrifugation, but the possible antibody content is most likely reduced by bacterial fermentation.

The observed tendency of the sterile-filtrated serum portions to give somewhat lower titers is probably due to a dilution effect. Unfortunately, complete dryness of the autoclaved filtration equipment before use was not ensured in all cases. When in experiments performed later on residual moisture in the Seitz disc is avoided, the filtration procedure causes no decrease in titer.

Although the growth-agglutination test is essentially a culture method the inhibitors allow bacteriologic aseptic technique to be deviated to a certain limit. This limit was not exceeded in this material by applying a serum dilution technique otherwise used in agglutination tests with killed antigen, and persons without training in bacteriological technique had no difficulties in carrying out the growth-agglutination test when using the selective medium.

As the test can be used by any laboratory without previous preparation and testing of a killed antigen, it is believed that 
the described modification of the growth-agglutination test will make this a fast and reliable aid in the differential diagnosis of arthritis and osteoarthropathies in swine.

\section{REFERENCES}

Collins, Douglas H. \& William Goldie: Observations on polyarthritis and on experimental erysipelothrix infection of swine. J. Path. Bact. 1940, 50, 323-353.

Freeman, M. J., D. Segre \& D. T. Berman: Hypersensitivity in erysipelas arthritis of swine. 1. Hypersensitization of swine with viable and non-viable Erysipelothrix. Amer. J. vet. Res. 1964, $25,135-144$.

Grey, C. G., O. L. Osteen \& H. W. Schoening: Swine erysipelas, the agglutination test for its diagnosis, and a report on a study of arthritis in swine. Amer. J. vet. Res. 1941, 2, 74-76.

Hubrig, Th.: Infektion, Immunität, Allergie am Beispiel Schweinerotlauf. (Infection, immunity and allergy with reference to swine erysipelas). Dtsch. Akad. Landwirtschaftswissenschaften. Sitzungsberichte X, Heft 9, Berlin 1961.

Nielsen, N. C.: Kronisk produktiv og deformerende polyarthritis hos grise. III. Serologiske unders $\varnothing$ gelser. (Chronic proliferative and deformating polyarthritis in pigs. III. Serologic investigations). Nord. Vet.-Med. 1969, 21, 225-243.

Rice, C. E., R. Connell, J. L. Byrne \& P. Boulanger: Studies of swine erysipelas. IV. Serological diagnosis in swine. Canad. J. comp. Med. 1952, 16, 209-215.

Schaaf, A. van der \& A. Kramer-Zeeuw: A stable antigen for the tube agglutination test in chronic swine erysipelas. Amer. J. vet. Res. 1968, 29, 205-207.

Schoening, H. W., G. T. Creech \& C. G. Grey: A laboratory tube test and a whole blood rapid agglutination test for the diagnosis of swine erysipelas. N. Amer. Vet. 1932, 13, 19-25.

Schoening, H. W. \& G. T. Creech: An agglutination test for swine erysipelas. J. Amer. vet. med. Ass. 1933, 82, 503-508.

Schoening, H. W. \& G. T. Creech: Swine erysipelas - with particular reference to serological diagnosis. J. Amer. vet. med. Ass. 1935a, $88,310-316$.

Schoening, H. W. \& G. T. Creech: Serological studies of swine erysipelas - with particular reference to agglutination. J. agric. Res. 1935b, 50, 71-79.

Sikes, D.: Some biochemic properties of a smooth colony of erysipelothrix insidiosa used for antigen production in the tube test. Amer. J. vet. Res. 1965, 26, 636-640.

Sikes, D. \& T. J. Tumlin: Further studies on the erysipelothrix insidiosa tube agglutination test. Amer. J. vet. Res. 1967, 28, 11771181. 
Watts, P. S.: Studies on Erysipelothrix rhusiopathiae. J. Path. Bact. 1940, 50, 355-369.

Wellmann, G.: Die subklinische Rotlaufinfektion und ihre Bedeutung für die Epidemiologie des Schweinerotlaufs. (The subclinical erysipelas infection and its epidemiological role). Zbl. Bakt., I. Abt. Orig. 1955, 162, 265-274.

Wellmann, G. \& F. Heuner: Bedeutung von serologischen Untersuchungen in der Schweinerotlaufforschung. (The importance of serologic investigations in studies on erysipelas). Zbl. Bakt., I. Abt. Orig. 1957a, 170, 91-97.

Wellmann, G. \& F. Heuner: Über die passiv durch die Kolostralmilch erworbene Rotlaufimmunität der Ferkel. (Transfer to piglets through colostrum of passive immunity to swine erysipelas). Zbl. Vet.-Med. 1957b, 4, 557-572.

Wellmann, G. \& F. Heuner: Beziehungen zwischen serologisch nachweisbaren Antikörpern und der Immunität beim Schweinerotlauf. (The correlation between circulating antibodies and the immunity in erysipelas). Zbl. Bakt., I. Abt. Orig. 1959, 175, 373 -387 .

Wellmann, G. \& H. Liebke: Über das Vermögen junger Ferkel, eine Rotlaufimmunität zu bilden. (The ability of baby pigs to develop erysipelas immunity). Zbl. Bakt., I. Abt. Orig. 1960, 177, 394402.

Wood, R. L.: A selective liquid medium utilizing antibiotics for isolation of Erysipelothrix insidiosa. Amer. J. vet. Res. 1965, 26, 1303-1308.

\section{SUMMARY}

The use of a phosphate-buffered horse-meat infusion broth $(\mathrm{pH}$ 7.8) containing neomycin sulphate $50 \mu \mathrm{g} / \mathrm{ml}$, kanamycin $400 \mu \mathrm{g} / \mathrm{ml}$ and vancomycin $25 \mu \mathrm{g} / \mathrm{ml}$ was compared with the medium without antibiotics in the E. insidiosa growth-agglutination test on sterile and contaminated, positive and negative swine and rabbit serums.

The addition of the inhibitory agents to the medium caused no visible growth depression on the 2 antigen strains employed - regardless of the percentage $(\leqq 40 \%)$ of specific hyperimmune serum content.

The use of the selective medium in testing hyperimmune serum revealed no significant difference in the recorded antibody titer as compared to the ordinarily used medium. The presence of some contaminants in the agglutinating system did not influence the results - provided that the multiplication of these organisms was inhibited (Table 1).

The inhibitory efficiency was tested on 161 contaminated swine serum samples and on 12 contaminated rabbit serums. None of the selective broth dilutions of these serums showed multiplication of contaminants during a $24 \mathrm{hrs}$. preincubation period or in a control tube after $48 \mathrm{hrs}$. incubation. 
The inhibitors allow bacteriologic aseptic technique in the procedure of the growth-agglutination test to be deviated to a certain limit. This limit was not exceeded in this material by applying a serum dilution technique otherwise used in agglutination tests with killed antigen.

As the described method eliminates the demand of complete aseptic bleeding and serum preparation procedures or an elaborious sterile filtration procedure, and since the test can be used by any laboratory without previous preparation and testing of a killed antigen, the growth-agglutination test is recommended as a fast and reliable aid in the differential diagnosis of erysipelas arthritis on herd basis in swine.

\section{ZUSAMMENFASSUNG}

Die Anwendung eines selektiven Züchtungsmedium in der Wachstumsprobe bei chronischen Rotlaufinfektionen beim Schwein.

Die Möglichkeit der Anwendung von Antibiotikainhibitoren bei der Durchführung einer Agglutinationsprobe mit multiplizierendem Antigen (Wachstumsprobe), im Hinblick darauf Rotlaufantistoffe nachzuweisen, ist untersucht worden.

Zur Serumverdünnung wurde eine Pferdefleischbouillon mit $1 \%$ Pepton, pH 7,8 (Phosphatpuffer) benutzt.

Als selektives Medium wurde dieselbe Bouillon, der Neomycin 50 $\mu \mathrm{g} / \mathrm{ml}$, Kanamycin $400 \mu \mathrm{g} / \mathrm{ml}$ und Vankomycin $25 \mu \mathrm{g} / \mathrm{ml}$ zugesetzt war, benutzt. Die Agglutinationsproben sind mit 2 Antigenstämmen an bzw. sterilen und kontaminierten, positiven und negativen Schweine- und Kaninchenseren vorgenommen worden.

Die Anwesenheit der Inhibitoren in den Bouillon-Serum-Verdünnungen verursachte keine nachweisbare Wachstumshemmung in den beiden benutzten Antigenstämmen unangesehen des prozentualen ( $\leqq$ $40 \%$ ) Gehalts des spezifischen Hyperimmunserums.

Es wurde kein signifikanter Unterschied in den erreichten Titern nach Anwendung von selektivem und nicht-selektivem Serumverdünnungsmedium festgestellt. Die Anwesenheit einer nicht erkennbaren Anzahl Kontaminanten in dem agglutinierenden System beeinflusste nicht die Ergebnisse - vorausgesetzt dass ein Wuchs der Kontaminanten verhindert wurde (Tabelle 1).

Die inhibitorische Wirkung der beigefügten Antibiotika wurde an 161 kontaminierten Schweine- und 12 kontaminierten Kaninchenseren untersucht. Es wurde kein Wuchs der Kontaminanten in den selektiven Bouillonverdünnungen dieser Seren nach 24 Stunden Vorinkubation bei $37,5^{\circ} \mathrm{C}$ konstatiert, und auch nicht in einer nicht okulierten Kontrollverdünnung nach 48 Stunden Inkubation.

Die Inhibitoren erlaubten weiter, dass von der bakteriologisch aseptischen Technik in so hohem Grade abgelassen wurde, dass die Serumverdünnungen in diesem Material auf entsprechende Weise vorgenommen werden konnten wie bei Agglutinationsproben mit getötetem Antigen, ohne dass ein unerwünschter Wuchs eintrat. 
Da die Forderung von entweder einer völligen aseptischen Blutentnahme und Serumpräparation oder einer vorausgehenden zeitraubenden Sterilfiltrierung bei Anwendung der beschriebenen Methode eliminiert werden kann, und weil die Probe in jedem bakteriologischen Laboratorium ohne vorausgehende Präparation und Prüfung eines getöteten Antigens vorgenommen werden kann, ist die BouillonAgglutinationsprobe mit lebendigem Antigen als eine schnelle und zuverlässige Hilfe bei der Differentialdiagnose der chronischen Rotlaufinfektionen in Schweinebeständen anzusehen.

\section{SAMMENDRAG \\ Anvendelse af antibiotika-inhibitorer $i$ bouillon-agglutinationsprøven for kronisk rødsygeinfektion hos svin.}

Muligheden for at anvende antibiotikainhibitorer ved udf $\varnothing$ relse af agglutinationsprøve med multiplicerende antigen (Wachstumsprobe) med henblik på påvisning af rødsygeantistoffer er undersøgt.

Til serumfortyndinger er anvendt en fosfatbufferet hestek $\varnothing \mathrm{ds}$ bouillon med $1 \%$ pepton, $\mathrm{pH} 7,8$.

Som selektivt medium er anvendt samme bouillon tilsat neomycinsulfat $50 \mu \mathrm{g} / \mathrm{ml}$, kanamycin $400 \mu \mathrm{g} / \mathrm{ml}$ og vankomycin $25 \mu \mathrm{g} / \mathrm{ml}$. Agglutinationsprøverne er udført med 2 antigenstammer på henholdsvis sterile og kontaminerede, positive og negative svine- og kaninsera.

Tilstedeværelsen af inhibitorerne i bouillon-serum-fortyndingerne forårsagede ikke nogen påviselig væksthæmning på de 2 anvendte antigenstammer uanset det procentvise $(\leqq 40 \%)$ indhold af specifik hyperimmunserum.

Der påvistes ingen signifikant forskel i de opnåede titre ved anvendelse af selektivt og ikke-selektivt serumfortyndingsmedium. Tilstedeværelsen af et ikke synligt antal kontaminanter i det agglutinerende system påvirkede ikke resultaterne - forudsat at vækst af kontaminanterne blev hindret (tabel 1).

Den inhibitoriske effekt af de tilsatte antibiotika blev unders $\varnothing$ gt på 161 kontaminerede svine- og 12 kontaminerede kaninsera. Der blev ikke konstateret vækst af kontaminanter i de selektive bouillonfortyndinger af disse sera efter 24 timers forinkubering ved $37,5^{\circ} \mathrm{C}$ eller i en utilsået kontrolfortynding efter 48 timers inkubation.

Inhibitorerne tillod endvidere, at bakteriologisk aseptisk teknik blev fraveget $i$ en sådan grad, at serumfortyndingerne i dette materiale kunne foretages på samme måde som ved agglutinationsprøver med dræbt antigen, uden at der fremkom uønsket vækst.

Da kravet om enten en fuldstændig aseptisk blodudtagning og serumpreparation eller en tidsrøvende forudgående sterilfiltrering elimineres ved anvendelse af den beskrevne metode, og da prøven kan udføres på ethvert bakteriologisk laboratorium uden forudgående preparation og afprøvning af et dræbt antigen, anses bouillonagglutinationsprøven med levende antigen for at kunne blive en hurtig og pålidelig hjælp i differentialdiagnosen af kroniske rødsygeinfektioner i svinebesætninger.

(Received October 28, 1968). 